\title{
Presence of Choline in Teichoic acid of Clostridium acetobutylicum N1-4 and Choline Inhibition of Autolytic Functions
}

\author{
By LAURENCE PODVIN, * GILLES REYSSET, JACQUES HUBERT AND \\ MADELEINE SEBALD
}

Unité des Anaérobies, Institut Pasteur, 25 rue de Dr Roux, 75724 Paris Cedex 15, France

(Received 1 December 1987; revised 17 February 1988)

\begin{abstract}
Addition of choline to growing Clostridium acetobutylicum led to abnormal cell septation, lack of cell separation and the consequent formation of chains. Similar results were obtained with the wild-type strain N1-4 and its autolysin-deficient mutant N1-4081. With strain N1-4, addition of choline at 1 to $2 \mathrm{mg} \mathrm{ml}^{-1}$ resulted in inhibition of autolysis assessed as autoplast formation in $0.6 \mathrm{M}$-sucrose, lysis by $0.3 \mathrm{M}-\mathrm{NaCl} / 0.03 \mathrm{M}$-sodium citrate, lysis by $0.1 \%$ Triton $\mathrm{X}-100$ and lysis by penicillin $\mathrm{G}$. In vitro data confirmed the inhibition by choline of wall-degrading activity, using N1-4 cell walls as substrate. Choline was shown to be a component of the teichoic acid of $C$. acetobutylicum N1-4.
\end{abstract}

\section{INTRODUCTION}

Recently, there has been renewed interest in butyl-acetone producing clostridia, since they may soon be used as biocatalysts in transformations for fuels and chemical feedstock. Before developing a programme of genetic engineering we need first to improve our basic knowledge of the physiology of these bacteria, and second to develop efficient gene-transfer systems which can be achieved by PEG-mediated protoplast transformation. It has already been described for Bacillus subtilis (De Castro-Costa \& Landman, 1977) that difficulties in protoplast regeneration are due to the production of an autolysin. We succeeded in protoplast regeneration in Clostridium acetobutylicum N1-4, which produces an $\mathrm{N}$-acetylmuramidase as lytic enzyme (Yoshino et al., 1982), both by using an autolytic deficient mutant N1-4081, and by adding to the regeneration medium sodium polyanethole sulphonate (Reysset et al., 1987) or choline (unpublished results), which is shown here to inhibit the autolytic activity.

We report here both in vivo and in vitro evidence for inhibition by choline of autolysin in $C$. acetobutylicum N1-4, together with evidence that choline is a component of the teichoic acid of this bacterium.

\section{METHODS}

Organisms. Clostridium acetobutylicum N1-4 (Hongo, 1960) and the autolysin-deficient mutant N1-4081 were used throughout. Mutant N1-4081 was obtained from N1-4080, a N1-4 mutant auxotriophic for proline (Reysset et al., 1987).

Media and growth conditions. Organisms were routinely grown at $35^{\circ} \mathrm{C}$ in TYA medium (Ogata \& Hongo, 1973). The $\mathrm{pH}$ was adjusted to 6.5 with $\mathrm{NaOH}$, and glucose was added to a final concentration of $1 \%(\mathrm{w} / \mathrm{v})$. Choline was added from a stock solution $\left(500 \mathrm{mg} \mathrm{ml}^{-1}\right)$ that was filter-sterilized $(0.45 \mu \mathrm{m}$ pore size, Millipore). All manipulations and culture incubations were done under conditions of strict anaerobiosis in an anaerobic glove box (Celster Isotechnic) with a controlled atmosphere: $\mathrm{N}_{2} / \mathrm{H}_{2} / \mathrm{CO}_{2}(90: 5: 5$, by vol.). Lysis and growth of bacterial cells were followed by measuring the optical density at $570 \mathrm{~nm}$ with a photoelectric colorimeter (Chemtrix, type 24).

Induction of autoplast formation by sucrose. N1-4 cells were grown in TYA until the culture reached an $\mathrm{OD}_{570}$ of about 0.6 and then adjusted with pre-weighed solid-sterilized sucrose to $0.6 \mathrm{M}$, followed by incubation at $35^{\circ} \mathrm{C}$ for $180 \mathrm{~min}$. The percentage of autoplasts was determined in a Petroff-Hausser chamber. 
Induction of bacterial lysis by $\mathrm{NaCl} /$ sodium citrate. Cells were grown in $200 \mathrm{ml}$ TYA and, at various times, $10 \mathrm{ml}$ samples of culture broth were withdrawn and $1 \mathrm{ml} 3 \mathrm{M}-\mathrm{NaCl} / 0 \cdot 3 \mathrm{M}$-sodium citrate ( $\mathrm{pH}$ unadjusted) was added (Ogata \& Hongo, 1973) together with different concentrations of choline ( 0 to $2 \mathrm{mg} \mathrm{ml}^{-1}$ ). Cultures were incubated at $35^{\circ} \mathrm{C}$ and $\mathrm{OD}_{570}$ readings were made at $10 \mathrm{~min}$ intervals. The final percentage lysis was estimated from the change in $\mathrm{OD}_{570} 100 \mathrm{~min}$ after addition of the lytic agent.

Lysis by Triton $X-100$. Various concentrations of choline ( 0 to $10 \mathrm{mg} \mathrm{ml}^{-1}$ ) were added to $10 \mathrm{ml}$ samples of culture in mid-exponential phase $\left(\mathrm{OD}_{570} 0 \cdot 5\right)$ before addition of $0 \cdot 1 \%(\mathrm{w} / \mathrm{v})$ Triton $\mathrm{X}-100$. Lysis was followed as described above.

Penicillin treatment. Cells were grown in TYA medium to an $\mathrm{OD}_{570}$ of about 0.6 and penicillin (Specillin G, Specia, Rhône Poulenc) was added at a concentration of $100 \mu \mathrm{g} \mathrm{ml}^{-1}$ together with various concentrations of choline ( 0 to $\left.2 \mathrm{mg} \mathrm{m}^{-1}\right)$. Growth and lysis of bacterial cells at $35^{\circ} \mathrm{C}$ were followed as above.

Cell wall preparation. This was done as described by Ogata et al. (1974).

Preparation of teichoic acid. A cell wall preparation $(10 \mathrm{ml})$ at an $\mathrm{OD}_{450}$ of 2 in $0.15 \mathrm{M}-\mathrm{NaCl} / 0 \cdot 01 \mathrm{M}-\mathrm{K}_{2} \mathrm{HPO}_{4}$, pH 8.0 was treated with $10 \mu \mathrm{g}$ DNAase I (Sigma) $\mathrm{ml}^{-1}$ and $50 \mu \mathrm{g}$ RNAase A (Sigma) $\mathrm{ml}^{-1}$ at $37^{\circ} \mathrm{C}$ for $4 \mathrm{~h}$. The pellet was resuspended in $3 \%(\mathrm{w} / \mathrm{v}) \mathrm{NaCl}$ and proteins were removed by three treatments with an equal volume of chloroform/isoamyl alcohol $(3: 1, \mathrm{v} / \mathrm{v})$. After centrifugation at $14000 \mathrm{~g}$ for $30 \mathrm{~min}$, the walls were freeze-dried and trichloroacetic acid was used to extract the teichoic acid according to Archibald (1971) with the following modifications : two extractions were made in $5 \%(w / v)$ TCA at $100{ }^{\circ} \mathrm{C}$ for $1 \mathrm{~h}$, and a third extraction in $10 \% \mathrm{TCA}$ at $4{ }^{\circ} \mathrm{C}$. The combined acid extracts were precipitated by addition of 5 vols cold ethanol. The crude teichoic acid precipitate was finally washed in cold absolute ethanol.

Detection of choline in teichoic acid. Crude teichoic acid was hydrolysed in a sealed tube with $6 \mathrm{M}-\mathrm{HCl}$ at $100^{\circ} \mathrm{C}$ for $18 \mathrm{~h}$. The hydrolysate was dried by rotary evaporation under vacuum; residual $\mathrm{HCl}$ was removed by 10 successive additions of a small volume of water and evaporating to dryness each time. Ethanol $(30 \mu l)$ was added to dissolve the hydrolysate which was analysed for the presence of choline by thin-layer chromatography on cellulose sheets (Schleicher and Schüll, F1440) as described by Augustinsson \& Grahn (1953). The chromatogram was stained according to Chargaff et al., (1948). The standards run were purchased from Sigma (see below).

Affinity chromatography on choline-Sepharose. Choline-Sepharose was prepared from expoxy-activated Sepharose 6B (Pharmacia). The general conditions were those of Briese \& Hakenbeck (1985), except that the elution buffer was $67 \mathrm{mM}$-potassium phosphate, pH 6.0, without detergent.

In vitro assay of lytic activity. Lytic activity was measured with cell walls of strain N1-4. The cell wall preparation was pre-incubated for $10 \mathrm{~min}$ with choline before adding different lytic enzymes. One unit of lytic activity (1 UA) was defined as a decrease in $\mathrm{OD}_{450}$ of $0.001 \mathrm{~min}^{-1}$ (spectrophotometer: DU7, Beckman). Activities were assayed at $35^{\circ} \mathrm{C}$ except for lysozyme, which was assayed at room temperature. Preliminary experiments were made to define the cell wall concentration corresponding to a non-limiting concentration of substrate for lytic activity up to $10 \mathrm{UA} \mathrm{ml}^{-1}$. The reaction mixture to assay supernatant activity from stationary phase cells contained: $50 \mu \mathrm{l}$ of N1-4 cell walls at an $\mathrm{OD}_{450}$ of $2 ; 350 \mu \mathrm{l} 0 \cdot 1 \mathrm{M}$-sodium acetate, $\mathrm{pH} 4 \cdot 5$, containing different concentrations of choline; $60 \mu \mathrm{l} 1 \mathrm{M}$-sodium acetate, $\mathrm{pH} 4 \cdot 5$, and $540 \mu \mathrm{l}$ of stationary phase culture filtrate. The assays with enzymes from a commercial source - lysozyme (EC 3.2.1.17) (Sigma; $59 \cdot 2$ units $\mathrm{mg}^{-1}$ ) and mutanolysin (Sigma; 303 units $\mathrm{mg}^{-1}$ ) - were done with lytic activities similar to the N1-4 supernatant activity. The reaction mixture contained: $50 \mu \mathrm{l}$ of N1-4 cell walls or Micrococcus lysodeikticus whole cells (Difco) at an $\mathrm{OD}_{450}$ of $2 ; 850 \mu 1 \mathrm{TYA}$ medium containing different concentrations of choline, and $100 \mu 1$ TYA medium containing the commercial enzyme preparation.

Electron microscopy. Cells were harvested by centrifugation during the exponential growth phase, fixed overnight in $1 \%(\mathrm{w} / \mathrm{v}) \mathrm{OsO}_{4}$ in $0.25 \mathrm{M}$-sodium cacodylate, $\mathrm{pH} \mathrm{7.2,} \mathrm{washed} \mathrm{repeatedly} \mathrm{with} \mathrm{the} \mathrm{same} \mathrm{buffer,}$ dehydrated in a graded acetone series, and embedded in Epon 812. Sections were cut with an LKB Ultratome Nova using a diamond knife, mounted on copper grids, stained in $2 \%(\mathrm{w} / \mathrm{v})$ uranyl acetate and $1 \%(\mathrm{w} / \mathrm{v})$ lead citrate and observed in a Philips CM12 electron microscope.

\section{RESULTS}

\section{Cell morphology}

In TYA medium, exponentially growing N1-4 cells consisted of short rods $3-6 \mu \mathrm{m}$ in length (Fig. 1a) with typical septa (Fig. 1c). Addition of choline at concentrations higher than $1 \mathrm{mg}$ $\mathrm{ml}^{-1}$ led to formation of long chains of more than 10 cells. Fig. $1(b)$ illustrates the cell morphology with $10 \mathrm{mg} \mathrm{ml}^{-1}$ choline. Electron microscopy showed abnormal septa that were thickened with accumulation of cell wall material (Fig. 1 d). This abnormal septation did not

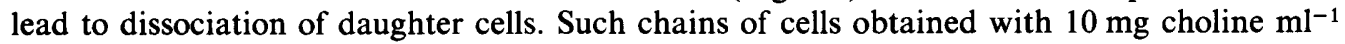
sheared when they were centrifuged and suspended in a crude supernatant of strain N1-4 (autolytic titre $4.6 \mathrm{UA} \mathrm{ml}^{-1}$ ) or in TYA containing $1 \mu \mathrm{g}$ lysozyme $\mathrm{ml}^{-1}$. In TYA medium, strain 

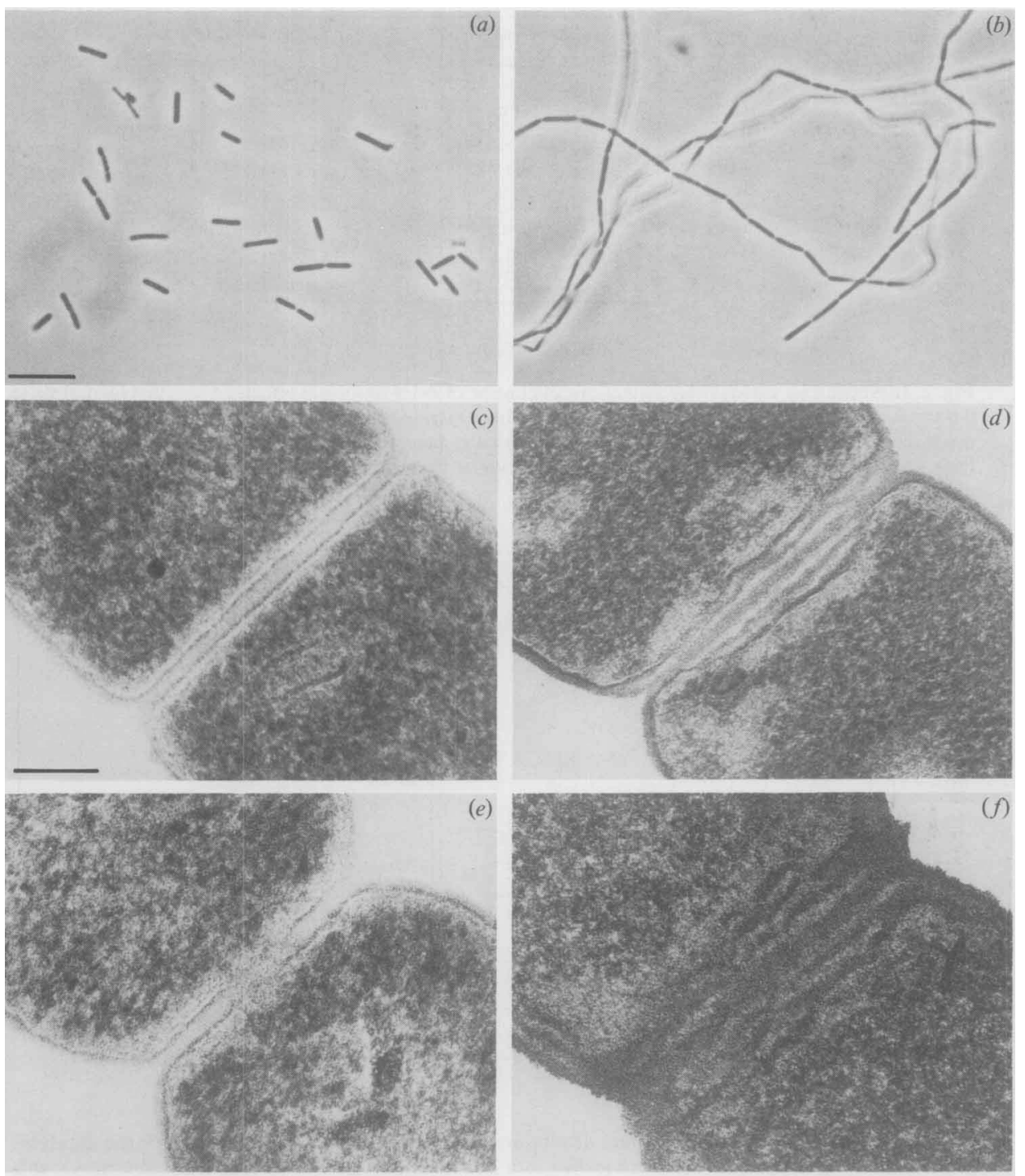

Fig. 1. Effect of choline on $C$. acetobutylicum cell morphology. Late exponentional phase N1-4 cells grown in the absence of choline $(a)$ and in the presence of $10 \mathrm{mg}$ choline $\mathrm{ml}^{-1}(b) .(c, d)$ Detail of the septa of strain N1-4 in the absence $(c)$ and presence $(d)$ of choline. $(e, f)$ Detail of the septa of strain N14081 in the absence $(e)$ and presence $(f)$ of choline. Scale bars are $10 \mu \mathrm{m}(a, b)$ and $0 \cdot 1 \mu \mathrm{m}(c, d, e$ and $f)$.

N1-4081 grew as short rods with normal septa (Fig. 1e) presumably due to residual autolytic activity (Reysset et al., 1987). In the same medium with $10 \mathrm{mg}$ choline $\mathrm{ml}^{-1}$, long chains of cells with abnormal septa were formed (Fig. $1 f$ ). Moreover, resuspension of these chains in TYA containing lysozyme or N1-4 crude filtrate of equivalent autolytic activity led to cell separation.

\section{Autoplast formation by $0.6 \mathrm{M}$-sucrose}

Maximum sucrose-induced autoplast formation was obtained with cells from the exponential phase $\left(\mathrm{OD}_{570} 0.5\right)$ (Reysset et al., 1987). Under these conditions, we observed an inhibition of autoplast formation by the addition of choline; complete inhibition was observed at $1.5 \mathrm{mg}$ choline $\mathrm{ml}^{-1}$ (Fig. 2). 


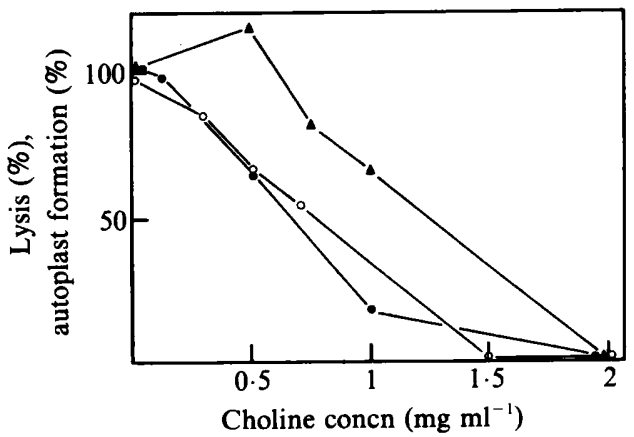

Fig. 2. Inhibition by various concentrations of choline of N1-4 autolysin effects. Autoplast formation in $0.6 \mathrm{M}$-sucrose $(O)$, lysis by $0.3 \mathrm{M}-\mathrm{NaCl} / 0.03 \mathrm{M}$-sodium citrate $(O)$, and lysis by $0.1 \%$ Triton $\mathrm{X}-100(\mathrm{~A})$ are shown. Autoplast formation and lysis were basically assayed as described in Methods. The extent of lysis was taken to be $100 \%$ after 100 min incubation with Triton $\mathrm{X}-100$ or $\mathrm{NaCl} /$ sodium citrate in the absence of choline.

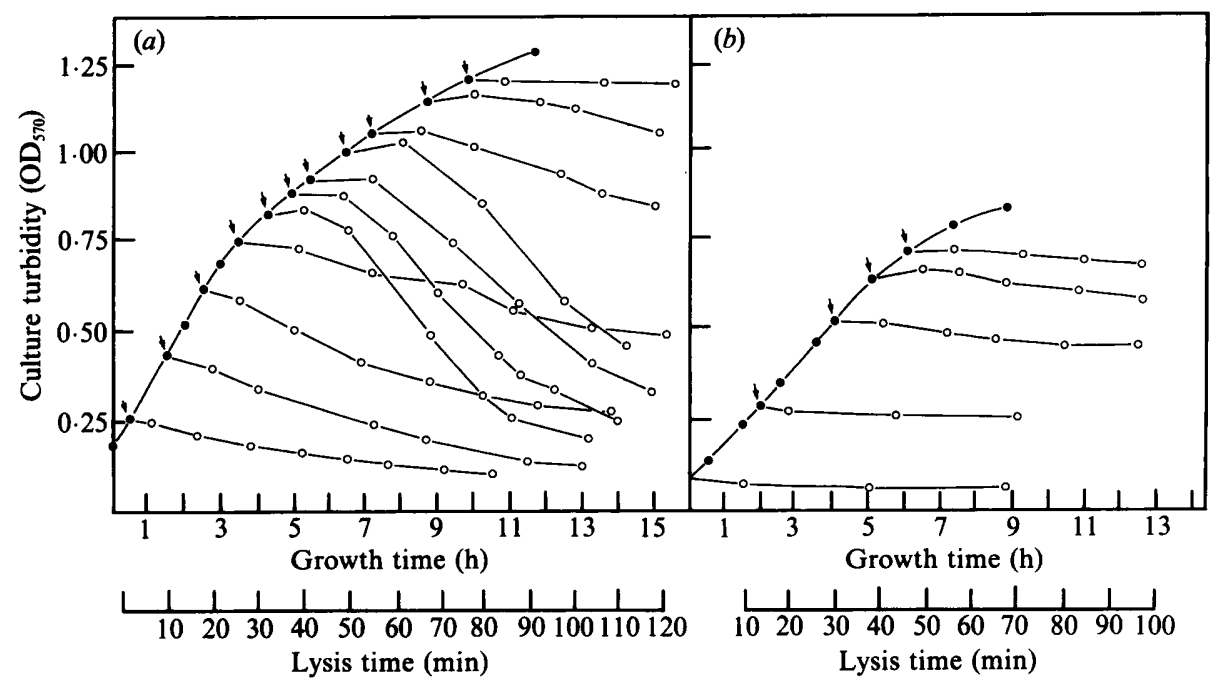

Fig. 3. Autolytic effect of $\mathrm{NaCl} /$ sodium citrate on (a) the wild-type strain N1-4 and (b) the autolytic deficient mutant N1-4081. Cells were grown in TYA medium (O). At various times during growth (indicated by arrows), samples were added to $0.3 \mathrm{M}-\mathrm{NaCl} / 0.03 \mathrm{M}$-sodium citrate, after which the $\mathrm{OD}_{570}$ was followed for $120 \mathrm{~min}(\mathrm{O})$.

With strain N1-4081, autoplasts did not appear in 0.6 M-sucrose and we were therefore unable to test the effect of choline. However, choline inhibited protoplast formation by lysozyme $\left(100 \mu \mathrm{g} \mathrm{ml}^{-1}\right)$ and penicillin $\left(20 \mu \mathrm{g} \mathrm{ml}^{-1}\right)$ (results not shown).

\section{$\mathrm{NaCl} /$ sodium citrate and Triton $\mathrm{X}-100$ induced lysis}

Ogata \& Hongo (1973) showed that strain N1-4 lysed in the presence of univalent cations, with rapid lysis in $\mathrm{NaCl}$ at 0.3 to $0.5 \mathrm{M}$; moreover, the rate of lysis was increased by sodium citrate. Under our experimental conditions, $0.3 \mathrm{M}-\mathrm{NaCl} / 0.03 \mathrm{M}$-sodium citrate had a maximum lytic effect at the end of the exponential growth of strain N1-4 (Fig. $3 a$ ) with $83 \%$ lysis in $100 \mathrm{~min}$.

Preliminary experiments on strain N1-4 showed optimal lysis with cells in the exponential phase, with $60 \%$ lysis after $100 \mathrm{~min}$ in the presence of $0 \cdot 1 \%$ Triton $\mathrm{X}-100$. The effect of various 


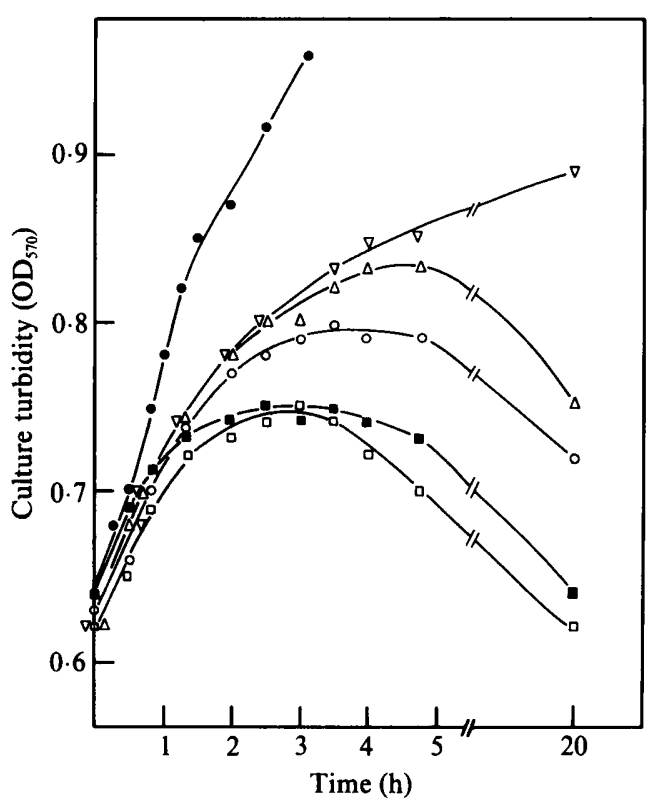

Fig. 4. Inhibition by choline of penicillin-induced lysis. At zero-time, mid-exponential phase cultures were treated with penicillin $\left(100 \mu \mathrm{g} \mathrm{m}^{-1}\right)$ and a range of concentrations of choline. No addition (O); addition of penicillin alone $(\square)$; addition of penicillin with choline at $0.5 \mathrm{mg} \mathrm{ml}^{-1}(\square), 0.75 \mathrm{mg} \mathrm{ml}^{-1}$ (O), $1 \mathrm{mg} \mathrm{ml}^{-1}(\triangle)$ or $2 \mathrm{mg} \mathrm{ml}^{-1}(\nabla)$.

concentrations of choline on lysis by $0.3 \mathrm{M}-\mathrm{NaCl} / 0.03 \mathrm{M}$-sodium citrate and by $0.1 \%$ Triton $\mathrm{X}$ 100 is shown in Fig. 2. In both cases complete inhibition of lysis was observed at $2 \mathrm{mg}$ choline $\mathrm{ml}^{-1}$.

No lysis was evident with the autolysin-deficient mutant N1-4081 under similar conditions; this is illustrated by the lack of lysis in the presence of $0.3 \mathrm{M}-\mathrm{NaCl} / 0.03 \mathrm{M}$-sodium citrate (Fig. $3 b)$.

\section{Lysis by penicillin $G$}

Autolytic enzymes should be involved in the bacteriolytic effect of $\beta$-lactam antibiotics (Rogers et al., 1980), as directly demonstrated in Streptococcus pneumoniae (Ronda et al., 1987). Strain N1-4 was shown to be sensitive to penicillin G at $100 \mu \mathrm{g} \mathrm{ml}^{-1}$ (Ogata et al., 1980). When penicillin was added at this concentration to exponentional cells of strain N1-4, lysis started $3.5 \mathrm{~h}$ after penicillin addition (Fig. 4). Addition of various concentrations of choline at the same time as penicillin (Fig. 4), or $15 \mathrm{~min}$ before (data not shown), resulted in inhibition of lysis, except at the lowest concentration of choline tested $\left(0.5 \mathrm{mg} \mathrm{ml}^{-1}\right)$. No significant lysis was observed in strain N1-4081 at the same concentration of penicillin.

\section{In vitro N1-4 autolytic activity}

A cell wall preparation from strain N1-4 was used as the substrate for an in vitro wall degradation assay (see Methods). Crude supernatant from a $24 \mathrm{~h}$ culture of strain N1-4 showed 4.6 $\mathrm{UA} \mathrm{ml}^{-1}$ in the assay, and this activity was strongly inhibited by addition of choline (Fig. 5). When commercially supplied mutanolysin and lysozyme were tested in the same assay, inhibition by choline required much higher concentrations. Degradation of $M$. lysodeikticus cells and the N1-4 wall preparation by commercial lysozyme were inhibited by choline to about the same'extent (Fig. 5). 


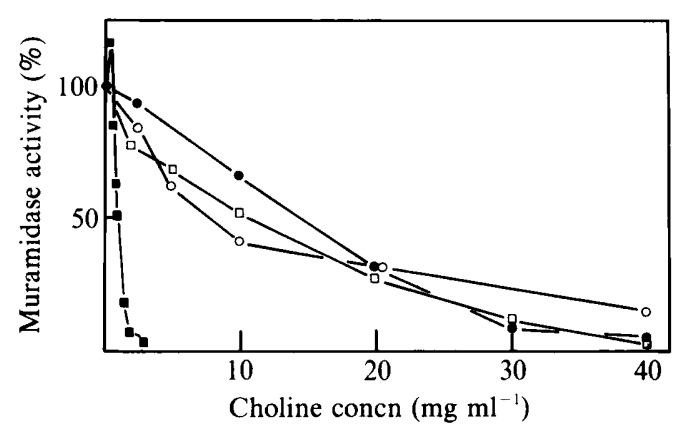

Fig. 5. Inhibition of different wall-degrading activities by choline. Activity $\left(\Delta O D_{450} \mathrm{~min}^{-1}\right.$, expressed as a percentage of the activity measured in the absence of choline) was measured with N1-4 supernatant $(\square)$, mutanolysin $(\square)$ or lysozyme $(O)$. An N1-4 cell wall preparation was used as substrate. Lysozyme was also tested with $M$. lysodeikticus cells as substrate (O).

\section{Presence of choline in the teichoic acid}

By using the technique described in Methods, a blue spot with the same $R_{F}$ value $(0 \cdot 38)$ as found for a choline standard was detected in the crude teichoic acid hydrolysate after separation on a thin-layer chromatogram. Various choline derivatives were similarly stained by the colour reagent, but they had different $R_{F}$ values, viz. choline dichloride (0.49), carbamylcholine chloride (0.32), phosphatidylcholine (0.87) and histamine (0.16).

\section{Affinity chromatography on choline-Sepharose}

A stationary phase culture of strain N1-4 was centrifuged and the supernatant was salted out with $\left(\mathrm{NH}_{4}\right)_{2} \mathrm{SO}_{4}$ at $60 \%$ saturation. The precipitate was dissolved in $67 \mathrm{~mm}$-potassium phosphate, pH 6.0 and extensively dialysed against the same buffer. After filtration $(0.45 \mu \mathrm{m}$ pore size, Millipore) and concentration by filtration on PM10 membrane (Amicon), the crude autolysin preparation contained $220 \mathrm{mg}$ protein $\mathrm{ml}^{-1}$ and $5200 \mathrm{UA}$ autolysin $\mathrm{ml}^{-1}$. The preparation $(8 \mathrm{ml})$ was applied to a choline-Sepharose column. Most of the enzyme activity was retained on the column during elution by $50 \mathrm{ml} 67 \mathrm{mM}$-phosphate buffer, $\mathrm{pH} 6 \cdot 0$, followed by $95 \mathrm{ml} 0.5 \mathrm{M}-\mathrm{NaCl}$ in the same buffer. Autolysin was eluted by $15 \mathrm{ml} 2 \%(\mathrm{w} / \mathrm{v})$ choline in the same buffer. Of the autolytic activity $84.6 \%$ was recovered from the eluate after extensive dialysis in 67 mM-phosphate buffer, pH 6.0.

\section{DISCUSSION}

In growing cells of $C$. acetobutylicum N1-4, choline inhibited cell separation, lysis by a nonionic surfactant (Triton X-100) and lysis by penicillin, all of which are related to autolytic activity in bacteria (Cornett \& Shockman, 1978; Guidicelli \& Tomasz, 1984; Rogers et al., 1980; Ronda et al., 1987). Moreover, choline had a pronounced effect on properties that are known to depend on endogenous autolysin production. Choline prevented sucrose-induced autoplast formation (Ogata et al., 1975), and cellular lysis induced by $\mathrm{NaCl} /$ sodium citrate (Ogata \& Hongo, 1973). The autolysin-deficient mutant N1-4081 (Reysset et al., 1987) was shown to have properties expected from an autolysin-deficient mutant.

The addition of high concentrations $\left(1-2 \mathrm{mg} \mathrm{ml}^{-1}\right.$ ) of choline to C. acetobutylicum $\mathrm{N1}-4$ had in vivo effects basically similar to those described in $S$. pneumoniae (Briese \& Hakenbeck, 1985; Guidicelli \& Tomasz, 1984).

The concentration of $1 \mathrm{mg}$ choline $\mathrm{ml}^{-1}$ inhibiting the in vitro extracellular $N$-acetylmuramidase of strain N1-4 is comparable to the concentration of $2.5 \mathrm{mg} \mathrm{ml}^{-1}$ required for $50 \%$ inhibition of lysis of $N$-acetylmuramyl-L-alanine amidase from $S$. pneumoniae (Briese \& Hakenbeck, 1984; Howard \& Gooder, 1974). When using N1-4 cell walls and lysozyme or 
mutanolysin, or $M$. lysodeikticus cells and lysozyme, choline concentrations 20 times higher than for the muramidase from $C$. acetobutylicum are required for complete enzyme inhibition. Such high concentrations can hardly be considered to act specifically.

We have shown choline to be a component of the N1-4 teichoic acid. S. pneumoniae was previously the only bacterium known to have a choline-containing teichoic acid (Brundish \& Baddiley, 1968; Mosser \& Tomasz, 1970) and lytic enzymes inhibited by exogenous choline (Höltje \& Tomasz, 1974; Sanchez-Puelles et al., 1986). The elution of N1-4 autolysin adsorbed to a choline-Sepharose column by a high choline concentration shows the affinity of the N1-4 autolysin for choline. As in S. pneumoniae amidase (Höltje \& Tomasz, 1974), choline residues in teichoic acid should be ligands for $C$. acetobutylicum autolysin.

We thank Dr M. Hongo for his gift of strain N1-4, and $\mathrm{H}$. Ohayon for electron microscopy facilities. This investigation was supported by research funds from Institut Français du Pétrole, and CNRS-PIRSEM grants nos. 3227 and 868 N1071. L. P. was the recipient of a fellowship from ANRT/Sucrerie d'Attin (convention CIFRE).

\section{REFERENCES}

ARChibald, A. R. (1971). Teichoic acids. Methods in carbohydrate chemistry 6, 162-172.

Augustinsson, K. B. \& GraHn, M. (1953). The separation of choline esters by paper chromatography. Acta chemica scandinavica 7, 906-912.

BRIESE, T. \& HAKENBECK, R. (1984). Influence of lipoteichoic acid and choline on the autolytic enzyme activity of Streptococcus pneumoniae. In Microbial Cell Wall Synthesis and Autolysis, pp. 201-206. Edited by C. Nombela. Amsterdam: Elsevier.

BRIESE, T. \& HAKENBECK, R. (1985). Interaction of the pneumococcal amidase with lipoteichoic acid and choline. European Journal of Biochemistry 146, 417427.

BRundish, D. E. \& Baddiley, J. (1968). Pneumococcal C-substance, a ribitol teichoic acid containing choline phosphate. Biochemical Journal 110, 573582.

Chargaff, E., Levine, C. \& Green, C. (1948). Techniques for the demonstration by chromatography of nitrogenous lipide constituents, sulfurcontaining amino acids, and reducing sugars. Journal of Biological Chemistry 175, 67-71.

CoRnetT, J. B. \& Shockman, G. D. (1978). Cellular lysis of Streptococcus faecalis induced with Triton X-100. Journal of Bacteriology 135, 153-160.

De Castro-Costa, M. R. \& Landman, O. E. (1977). Inhibitory protein controls the reversion of protoplasts and $\mathrm{L}$ forms of Bacillus subtilis to the walled state. Journal of Bacteriology 129, 678-689.

Guidicelli, S. \& Tomasz, A. (1984). Attachment of pneumococcal autolysin to wall teichoic acids, an essential step in enzymatic wall degradation. Journal of Bacteriology 158, 1188-1190.

HöltJE, J. V. \& Tomasz, A. (1974). Specific recognition of choline residues in the cell wall teichoic acid by the $N$-acetylmuramyl-L-alanine amidase of Pneumococcus. Journal of Biological Chemistry 250, 6072-6076.

HoNGo, M. (1960). US patent no. 2945786.

HowARD, L. V. \& GOODER, H. (1974). Specificity of the autolysin of Streptococcus (Diplococcus) pneumoniae. Journal of Bacteriology 117, 796-804.

Mosser, J. L. \& Tomasz, A. (1970). Choline-contain ing teichoic acid as a structural component of pneumococcal cell wall and its role in sensitivity to lysis by an autolytic enzyme. Journal of Biological Chemistry 245, 287-298.

Ogata, S. \& Hongo, M. (1973). Bacterial lysis of Clostridium species. I. Lysis of Clostridium species by univalent cation. Journal of General and Applied Microbiology 19, 251-261.

Ogata, S., Umeda, A. \& Hongo, M. (1974). Bacterial lysis of Clostridium species. Effect of fradiomycin on the activities of various lytic enzymes active toward Clostridium saccharoperbutylacetonicum. Journal of the Faculty of Agriculture, Kyushu University 19, 4959.

Ogata, S., Choi, K. H. \& Hongo, M. (1975). Sucroseinduced autolysis and development of protoplastlike cells of Clostridium saccharoperbutylacetobutylicum. Agricultural and Biological Chemistry 39, 12471254.

Ogata, S., Choi, K. H., Hongo, M. \& Hayashida, S. (1980). Studies on sucrose-induced autolysis of clostridial cells. 1. Induction of a rapid bacterial autolysis by sucrose treatment. Journal of the Faculty of Agriculture, Kyushu University 25, 33-45.

Reysset, G., Hubert, J., Podvin, L. \& Sebald, M. (1987). Protoplast formation and regeneration of Clostridium acetobutylicum strain N1-4080. Journal of General Microbiology 133, 2595-2600.

Rogers, H. J., Perkins, H. R. \& Ward, J. B. (1980). Microbial Cell Walls and Membranes, pp. 437-460. London: Chapman \& Hall.

Ronda, C., Garcia, J. L., Garcia, E., SanchezPuElles, J. M. \& LOPEZ, R. (1987). Biological role of the pneumococcal amidase. Cloning of the lyt $A$ gene in Streptococcus pneumoniae. European Journal of Biochemistry 164, 621-624.

Sanchez-Puelles, J. M., Ronda, C., Garcia, E., Mendez, E., Garcia, J. L. \& Lopez, R. (1986). A new peptidoglycan hydrolase in Streptococcus pneumoniae. FEMS Microbiology Letters 35, 163-166.

Yoshino, S., Ogata, S. \& HaYashida, S. (1982). Some properties of autolysin of Clostridium saccharoperbutylacetonicum. Agricultural and Biological Chemistry 46, 1243-1248. 